\title{
Herbicides for weed control in eucalypt ${ }^{1}$
}

\section{Herbicidas para o controle de plantas daninhas em eucalipto}

\author{
Fernanda Campos Mastrotti Pereira ${ }^{2}$; Pedro Luis da Costa Aguiar Alves ${ }^{3}$
}

\begin{abstract}
To ensure the maximum forestry productivity the adoption of efficient managements is essential. Weed control is very important, since presence of weeds can lead to competition for key factors to plant development. Weed interference can cause losses of up to $50 \%$ in productivity and over $90 \%$ of reduction in the profitability of forestry areas. Chemical control is widely used in weed management and about $30 \%$ of the total costs of production and up to $50 \%$ of the work force used in eucalypt crop cycle are intended for this purpose. Brazilian forestry sector has great economic expressiveness, but there are few herbicides registered. Chemical weed control should still fit the standards required by eucalypt certifications. The expansion of sector and the economic importance of this crop in Brazil make necessary the development of new herbicides and new spraying techniques to increase herbicides efficiency, new research, as well as encouraging adoption of an integrated weed management plan in eucalypt.
\end{abstract}

Keywords: Eucalyptus; glyphosate; reforestation; weed competition; weed management

Resumo - Para garantir a máxima produtividade florestal, a adoção de um manejo eficiente é essencial. O controle de plantas daninhas é muito importante, já que a presença dessas pode ocasionar competição por fatores fundamentais ao desenvolvimento das plantas. A interferência das plantas daninhas pode ocasionar perdas de até $50 \%$ na produtividade e mais de $90 \%$ de redução na rentabilidade das áreas florestais. O controle químico é amplamente utilizado no manejo das plantas daninhas, e cerca de $30 \%$ dos custos totais de produção e mais de $50 \%$ da mão-de-obra utilizada na cultura do eucalipto são destinadas para esse propósito. O setor florestal tem uma grande expressividade econômica, mas poucos herbicidas são registrados. O controle químico ainda deve se encaixar aos padrões requeridos pelas certificadoras. A expansão do setor e a importância econômica do eucalipto no Brasil fazem necessário o desenvolvimento de novos herbicidas, novas tecnologias de aplicação, novas pesquisas, bem como a adoção de um plano de manejo integrado de plantas daninhas em eucalipto.

Palavras-chaves: Eucalyptus; glyphosate; reflorestamento; matocompetição; manejo de plantas daninhas

\section{Introduction}

Eucalyptus is a genus belonging to Myrtaceae family and the number of species can vary from 500 to over 800 (Florence, 2004; Coppen, 2005). Eucalyptus species are largely used in forestry because of their rapid growth, good adaptation to different environmental

\footnotetext{
${ }^{1}$ Received for publication on 10/11/2015 and approved on 24/11/2015.

2 Doutoranda em Agronomia, Universidade Estadual Paulista "Júlio de Mesquita Filho" (UNESP) Faculdade de Ciências Agrárias e Veterinárias, Câmpus de Jaboticabal, Via de acesso prof. Donato Castellane, s/n, CEP 14884-900, Jaboticabal, SP. E-mail: <fernandamastrotti@ hotmail.com>. (Autor para correspondência).

${ }^{3}$ Professor Adjunto, Universidade Estadual Paulista "Júlio de Mesquita Filho" (UNESP) Faculdade de Ciências Agrárias e Veterinárias, Câmpus de Jaboticabal, Via de acesso prof. Donato Castellane, s/n, CEP 14884-900, Jaboticabal, SP. E-mail: <plalves@fcav.unesp.br>.
} 
conditions and wide possibilities of uses for its wood.

Eucalypt areas are essential to provide products such as pulpwood, paper, strand board, fiberboard and saw timber (Rockwood and Peter, 2011). According to Brazilian Industry of Trees (IBA, 2014) 5.4 million hectares were planted with Eucalyptus species. Brazil has a "relatively small forest area" compared to other countries, but contributed with $17 \%$ of all wood harvested in the world in 2013 (IBA, 2014).

To ensure and increase forest yield, good management is required. Fertilization, species/clones adapted to climatic conditions and management of weeds, pests and diseases are some of essential techniques to ensure the success of forest areas.

Weeds are a major problem in eucalypt, and can cause yield reduction and increase production costs due to high demand for manpower expended in weed control (Tuffi Santos et al., 2006; Silva et al., 2012). Invasive species are usually found in eucalypt areas as early as preparing the soil for planting and in absence of proper management can remain until harvest. Seedlings and young trees are very sensitive to weed competition, especially during establishment (Adams et al., 2003; Florentine and Fox, 2003; Garau et al., 2009; Cruz et al., 2010; Pereira et al., 2013, among others).

Weeds coexistence can cause a number of physiological and morphological changes, which can result in reductions in plants growth, quantity and quality of wood (Osiecka and Minogue, 2015).

According to Hakamada et al. (2010) weed interference can cause losses of up to 50 $\%$ in eucalypt yield and reduction of over $90 \%$ in the profitability of forestry enterprise. About $30 \%$ of total production cost and up to $50 \%$ of manpower used in eucalypt cycle is intended for weed control.

The purpose of this literature review is to gather key information related to herbicides for eucalypt, its effects on weed control and, in some cases, on eucalypt plants. To this end, a brief approach about weed interference and the main species that compose the weed community in forest areas were described, as well as the outlook for the chemical control in forest sector.

\section{Interference and Main Weeds in Eucalypt in Brazil}

Weed interference may be direct (e.g., competition and allelopathy) and indirect (e.g., host of pests and diseases, or even interfering with fertilization, irrigations and harvest) (Souza et al., 2003). In eucalypt plantation, weeds can also increase the risk of forest fires.

In forests the main form of weed interference is competition for water, nutrients, light and other resources necessary for both species (Souza et al., 2010). Thus, weeds must be controlled before interference is established.

In Brazil, many of current high yield forest plantations were traditional pastures areas for many years, so grasses stand out among the major weeds (Pereira et al., 2013 and others).

According to Pereira et al. (2012) the main weeds in Boa Esperança do Sul - São Paulo were $U$. decumbens, Sida glaziovii, Croton glandulosus and Sida rhombifolia. In Viçosa - Minas Gerais, Tiburcio et al. (2012b) reported as main weeds Amaranthus retroflexus, Bidens pilosa, Conyza bonariensis, Galinsoga parviflora, Ipomoea grandifolia, Euphorbia heterophylla, Spermacoce latifolia, Brachiaria plantaginea, Commelina benghalensis, Digitaria horizontalis and Eleusine indica.

Tuffi Santos et al. (2013) studied the floristic composition and structural variation of weeds in Minas Gerais. The most representative families were Poaceae, Asteraceae and Fabaceae. The most abundant species was Galinsoga parviflora. Emilia coccinea, Sida rhombifolia and Spermacoce latifolia were common to all areas.

\section{Negative Effects of Weeds in Eucalypt}

Negative impacts of weeds can begin soon, resulting in death of new seedlings in highly infested areas. In general, weed 
interference in eucalypt is more severe in the first year but may extend until the second year, especially in the presence of grasses and unwieldy species (Garau et al., 2009; Pereira et al., 2012; Pereira et al., 2013, among others.). In the absence of ideal management, weeds can stay for some or all the crop cycle, resulting in reduction in the plant growth, health or yield (Agostinetto et al., 2010).

After testing crown diameters (weed free distance around plants), Machado et al. (2013) concluded plants without crowning showed lower growth. Crown diameters about $2 \mathrm{~m}$ provided favorable conditions for initial growth of eucalypt seedlings.

Graat et al. (2015) evaluated coexistence effects between one Urochloa decumbens or $U$. ruziziensis positioned at distances $(0$ to $40 \mathrm{~cm})$ from one Eucalyptus urograndis plant $(\mathrm{C} 219 \mathrm{H}$ or H15 clones). Plants grown free of weeds showed higher height, stem diameter, stem dry mass and leaves dry mass than plants grown in coexistence. However, the distance between them was not a significant factor.

Long-term impact of weed control has also been documented by Little et al. (2003), testing cover crops, chemical control, mechanical control and hand-weeding during establishment of a hybrid resulting from the crossing of Eucalyptus grandis and E. camaldulensis. Eucalypt performance was improved and the variability between trees decreased as weed-free area increased. After 7 years tree volume in weed free areas was by 42.5 $\%$ greater compared to weedy areas.

However, some studies have found that eucalypt plants have potential for recovery even after the initial coexistence with weeds (Garau et al., 2009; Tarouco et al., 2009). This ability can possibly be explained by the long cycle, great ability to absorb and use nutrients and excellent growth and development of clones placed into suitable conditions. However, studies to evaluate trees until harvest are still scarce. To assess the recovery of plants, longer studies are needed.
In forestry areas second coppice rotation (after harvest, roots and a small part of stem are kept intact, and sprouts will form a new tree) has also used and its main advantage is low cost. Eucalyptus grandis plants in a second coppice area in coexistence with Urochloa decumbens and Panicum maximum did not show reductions in height, diameter and macronutrient levels after up to 18 months of coexistence. Reductions were found only when the weed free and weedy plots were compared (Souza et al., 2010). It is important to note in these conditions the root system was fully formed and reaching greater depths in soil. Probably, those eucalypt trees do not compete with weeds for growth resources.

Among the negative effects that occur due to weeds presence, depreciation of wood quality is very important. Species such as vines (Ipomoea grandifolia, I. aristolochiaefolia, I. purpurea) can be rolled along eucalypt stem, difficult their growth and induce the formation of side shoots that depreciate wood quality and consequently the wood amount and its sale price.

\section{Weed Chemical Control}

During the last years chemical control was the method widely used in eucalypt areas (lower cost and less manpower dependence). George and Brennan (2002) compared hand weeding, inter row slashing, cover crops, mulching and herbicide applications during establishment of Eucalyptus dunnii and E. saligna plantations in Australia. Herbicides were the most cost-effective weed control method.

Usually two to five herbicides applications are performed in the first year of eucalypt cycle, involving herbicides in pre and post-emergence of weeds. However, in some cases, the weed control extends for six years and is mainly performed in order to facilitate harvesting (Tuffi Santos et al., 2006). For an efficient weed control and/or to ensure the selectivity of herbicides over eucalypt plants, it 
is necessary to use herbicides in suitable concentrations and in the development stage recommended by manufacturer.

For adequate coverage of target, it is necessary to know the deposition characteristics provided by the equipment, herbicide and spray technology (Ferreira et al., 2009). Spraying nonselective post-emergence herbicides should be very cautious, as it may cause injuries and losses due to drift (Tiburcio et al., 2012b). The choice of herbicide to be used should consider weed species, development stage, climatic conditions (season, daily and in the spraying time), use of ideal spraying technology and water quality.

It is essential to consult the herbicides guidelines in Brazil (Rodrigues and Almeida, 2005; 2011; Brasil, 2015) as well as herbicides restrictions lists in certified forest areas (such as ISO 14001; Forest Stewardship Council - FSC or any other forest certification).

\section{Opportunities to Perform Weed Chemical Control}

Chemical control can be performed in three distinct times using different kinds of herbicides: (1) burndown; (2) pre-emergence herbicides, or (3) post-emergence herbicides.

\section{Burndown or Chemical Control Before Planting}

The implementation of a new area should always be held in a weed-free place. At that time non-selective herbicides with broadspectrum control, such as glyphosate, can be used safely.

Burndown can be performed in one or two steps based on weed species found in the area. It have to be done in two steps when the weed community is very developed (after the first spraying small weeds will still be alive, once they are protected from taller plants); when perennial species with hard control are identified (local species, for example); on the delay in carrying out the planting after burndown (logistics or weather problems may delay planting) and in the presence of tolerant species and/or resistant species. In these last two cases, herbicides with different sites of action must be sprayed. Glufosinate-ammonium, carfentrazone-ethyl and glyphosate are the most widely used herbicides for desiccation.

\section{Chemical Control with Pre-emergence Herbicides}

Here, the knowledge of weed infestation history is essential, and may be obtained by soil sampling for evaluation of soil seed bank (however not all species in the seed bank will develop in the area) or by observation and identification of species.

Soil characteristics (soil type, clay and organic matter contents) and the annual rainfall of area should be known, ensuring the correct dose of herbicide will be used (Rodrigues and Almeida, 2011).

Pre-emergence applications can be performed when needed, even after planting. Although, for some herbicides, as isoxaflutole, the selectivity for eucalypt can decreases as seedlings adapt to the soil conditions and grow. Possibly soon after planting the seedlings hardly absorbs isoxaflutole, and the selectivity of isoxaflutole sprayed in leaves was reported by Agostinetto et al. (2010). However, after seedling stablishing, isoxaflutole phytotoxic can be increased, as well as other pre-emergence herbicides in eucalypt. In forest areas these herbicide are sprayed on the same day the seedlings are planted, or a couple days later. Different spray techniques can be necessary to protect seedlings in late applications. The selectivity of an herbicide may vary depending on dose, eucalypt species or clone, climatic and soil conditions. Studies or preliminary tests should be performed for each situation.

Isoxaflutole, oxyfluorfen, pendimethalin, sulfentrazone and trifluralin are the most used herbicides for eucalypt at this time (Rodrigues and Almeida, 2011). They can be applied before or after planting, in preemergence or early post-emergence of weeds. It is always necessary to refer to herbicide label for instructions. 
Chemical Control in Post-emergence of Weeds

Herbicides sprayed after weeds emergence have limitations about species control and weed growth stage, which makes necessary the correct identification of species, as well as carrying out the spraying at correct time.

These herbicides may or may not be selective to eucalypt, and based on that knowledge can some of them have to be sprayed directed only on the weed community (nonselective). For a non-selective herbicide sprayed in post- emergence of weeds and after eucalypt planting, all the necessary procedures to avoid drift must be taken.

Among the main causes of drift, one can mention droplet size, height of the spray tip, operating and wind speed, temperature, air humidity, application volume and formulation used (Ferreira et al., 2009). The use spray nozzles which produce large droplets is also recommended.

Once again, refer to herbicide label before start herbicide use is always necessary.

\section{Herbicides for Eucalypt in Brazil}

Forest sector has great economic importance in Brazil, but there are few herbicides registered in comparison with other important crops or other eucalypt producing countries.

Herbicides that can be sprayed in eucalypt are glufosinate-ammonium, carfentrazone-ethyl, fluazifop-p-butyl, flumioxazin, glyphosate, isoxaflutole, oryzalin, oxyfluorfen, pendimenthalin, sulfentrazone, trifluralin and imazapyr (the last one exclusively for the eradication of areas) (Brasil, 2015; Rodrigues and Almeida, 2005; 2011). To facilitate understanding, herbicides were grouped according to mechanism of action.

\section{PROTOX inhibitors}

This group of herbicides inhibits the protoporphyrynogen oxidase (PROTOX). The accumulation of protoporphyrinogen IX will catalyze singlet oxygen formation, which causes lipid peroxidation in cell membranes. Lipids and proteins will be oxidized, causing loss of chlorophyll and carotenoids, resulting in dehydration and disintegration of organelles (Oliveira Jr. et al., 2011).

PROTOX inhibitors can be sprayed before weed emergence, but may also be used after the emergence of weeds. For good results spraying of PROTOX inhibitors, it is ideal that the soil is prepared and free from soil clods. In general, absorbed by roots, stems or leaves in newly germinated seedlings, with little or no translocation. The first symptom to be observed is the bleaching of leaves; followed by necrotic spots/drying areas and plant death (Oliveira Jr. et al., 2011).

\section{Carfentrazone-ethyl}

Carfentrazone-ethyl has shown good efficiency in the control of glyphosate tolerant species (Rodrigues and Almeida, 2011). However, is non-selective to eucalypt, requiring the spray solution must be carefully directed to target species and spray nozzles with protection should be used.

After a drift simulation of carfentrazoneethyl on Eucalyptus urophylla, Tuffi Santos et al. (2006) found the first symptoms of phytotoxicity 2 days after spraying, which culminated in the death of meristems and reduced shoot and root dry mass.

\section{Flumioxazin}

The efficiency of weed control and phytotoxicity in $E$. grandis by flumioxazin isolated or mixed with isoxaflutole or sulfentrazone was tested. Flumioxazin was totally selective to eucalypt at the $125 \mathrm{~g}$ a.i. $\mathrm{ha}^{-1}$ (some phytotoxicity effect was observed which was fully recoverable with plant growth). However, the efficiency of weed control was better when flumioxazin was mixed with isoxaflutole or sulfentrazone (Tiburcio et al., 2012a). 


\section{Oxyfluorfen}

Oxyfluorfen should be sprayed as soon as seedlings are planted, preferably on wet soil, free of crop residues and others material. For eucalypt plants with hairy leaves, spraying on seedlings is not recommended and the spraying jet must be directed to the soil. In the literature different levels of selectivity have been reported to different species.

Agostinetto et al. (2010) reported chlorosis and necrosis in young $E$. grandis leaves. However, the residual effect was efficient to control Brachiaria decumbens and Panicum maximum. Over-the-top sprayings of oxyfluorfen reduced the invasive vegetation in a Eucalyptus macarthurii area, promoting high tree height compared with directed glyphosate sprayings (Blazier et al., 2012).

\section{Sulfentrazone}

The major symptoms observed after sulfentrazone drift in eucalypt are purple leaves, necrosis, leaves with deformations and loss of apical dominance (Carbonari et al., 2012). Those symptoms can start from the seventh day after spraying (Takahashi et al., 2009). According to Velini et al. (2005), leaves formed between planting and spraying demonstrated greater sensitivity to sulfentrazone.

Takahashi et al. (2009) sprayed sulfentrazone doses 80 days after planting $E$. urograndis (VCP1 and VCP2 clones). Height and leaf area, respectively, were reduced between 9 and $66 \%$. At 35 days after spraying plants recovery was not observed.

Two sulfentrazone spraying systems were carried out by Carbonari et al (2011): (1) clay granules with sulfentrazone and (2) regular liquid spraying. Sulfentrazone at $750 \mathrm{~g}$ ai ha ${ }^{-1}$ showed better control of Brachiaria decumbens and Panicum maximum for the aerial application with clay granules.

After spraying sulfentrazone (400 and $600 \mathrm{~g} \mathrm{ha}^{-1}$ ) in four Eucalyptus urograndis clones (FB1, FB2, FB3, FB4), Carbonari et al. (2012) noted that clone FB3 showed greater dry mass reduction when compared to the other clones, and this reduction can be directly associated with the high levels of phytotoxicity observed. The concentrations of sulfentrazone absorbed by the plants were proportional to the dry mass reductions, indicating that variations in the eucalypt clones may be related to the differentiated absorption of the sulfentrazone.

\section{ACCase inhibitor \\ Fluazifop-p-butyl}

Fluazifop-p-butyl is predominantly absorbed by leaves and act inhibiting the acetylCoA carboxylase enzyme (ACCase), essential for lipids synthesis and so far production of phospholipids necessary for new membranes formation, essential for cell growth (Oliveira Jr. et al., 2011).

Inhibitors of ACCase are always sprayed as post-emergence herbicides and are indicated to control grass species. The ideal stage for spraying grasses is between 3 and 5 leaves, but may also be effective in bigger plants, especially in presence of an appropriate adjuvant. They are selective for dicotyledonous, plants which usually do not show the susceptible form of the enzyme ACCase (Oliveira Jr. et al., 2011).The effectiveness of weed control by ACCase inhibitor herbicides is dependent on environmental conditions and monitoring them before and during spraying is essential. Since fluazifop-p-butyl is toxic only for monocotyledonous, drift studies are not necessary.

\section{EPSPs inhibitor \\ Glyphosate}

Glyphosate is absorbed by leaves through the cuticle and is translocated to new leaves and meristems. It is a systemic herbicide which inhibits the enzyme 5-enolpyruvyl shikimate 3-phosphate synthase (EPSPs), blocking the synthesis of the amino acids phenylalanine, tyrosine and tryptophan essential for the synthesis of proteins and secondary metabolites (Bradshaw et al., 1997). The progressive yellowing of leaves is the first 
sign of toxicity, followed by wilting and necrosis (Tuffi Santos et al., 2005).

Glyphosate has many suitable characteristics to forest management, such as high spectrum of action and high efficiency in weed control. Nonetheless, glyphosate does not provide residual effects what requires frequent applications, resulting in signficant costs, drift risks and glyphosate tolerant/resistance species.

Glyphosate has been used in applications before planting (burndown); on weed control and eucalypt regrowth control; maintenance of areas free of weeds in the first year (usually more than once spraying is performed); in annual applications throughout the crop cycle (in order to prevent bank of seeds increasing, formation of sub-woods among trees, to facilitate fertilization and improve the use of fertilizer) and before harvest in order to make it easy. According to Hakamada et al. (2010), almost $100 \%$ of forest companies used glyphosate for weed control in 2010.

Pereira et al. (2012) evaluated glyphosate performance in an area with high infestation of Urochloa decumbens, Sida glaziovii, Croton glandulosus and Sida rhombifolia. Ten days after glyphosate spraying weed control was between 85 and $100 \%$ of the plants. At 30 days after glyphosate spraying, control of $U$. decumbens ranged between 80 and $85 \%$, with increasing regrowth. For other species, control ranged between 75 and $85 \%$.

Despite glyphosate use advantages, accidental drift on eucalypt plants has been frequently reported in forest areas. Even with caution, recent papers showed how is common glyphosate contact with leaves closest to soil. Herbicide drift symptoms have also been observed in surrounding areas (Takahashi et al., 2009).

A glyphosate drift simulation in five eucalypt species (E. grandis, E. urophylla, E. saligna, E. pellita and E. resinifera) was performed by Tuffi Santos et al. (2006) indicating that 172.8 and $345.6 \mathrm{~g} \mathrm{ha}^{-1}$ of glyphosate caused death of the apex of the plants 15 days after spraying. E. resinifera was more tolerant even when exposed to higher doses.

In a study of glyphosate drift effects on eucalypt clones, Tuffi Santos et al. (2007) observed a progression of injury symptoms from leaf chlorosis through necrosis and plant death. The eucalypt phytotoxicity increased as glyphosate rate was increased, and plants exposed to 173 or $346 \mathrm{~g}$ a.e. $\mathrm{ha}^{-1}$ displayed severe phytotoxicity symptoms, including reductions in height, stem diameter and dry mass 50 days after spraying.

Pereira et al. (2011) simulated a glyphosate drift $\left(40 ; 80 ; 160\right.$ and $240 \mathrm{~g}$ a.e. ha ${ }^{-}$ ${ }^{1}$ ) in leaves, stem and whole E. grandis plants. Eucalypt phytotoxicity increased with increasing glyphosate doses and had greater intensity when stem and whole plant were sprayed. As a result of glyphosate drift up to $58 \%$ losses in dry mass, $56 \%$ less leaf area and a difference of $6 \mathrm{~cm}$ in height gain of the plants were still observed.

Salgado et al. (2011) reported glyphosate negative effects in E. urograndis after a drift simulation on leaves and stems. Between three and seven months after planting plants that received doses above $144 \mathrm{~g}$ a.e. $\mathrm{ha}^{-1}$ showed reduction in yield 68 months after planting. But when drift simulation was held nine months after planting, doses of up to $432 \mathrm{~g}$ a.e. ha $^{-1}$ did not cause negative effects on yield. Carvalho et al. (2015) described Eucalyptus urograndis clones I144 and GG100 as more susceptible to glyphosate, showing the doses required to reduce dry mass by $50 \%$ of 113.4 and $119.6 \mathrm{~g}$ a.e. $\mathrm{ha}^{-1}$, respectively. The clones C219 and I224 were less susceptible to glyphosate, showing the doses required to reduce dry mass by $50 \%$ of 237.5 and $313.5 \mathrm{~g}$ ae $\mathrm{ha}^{-1}$, respectively.

Studies to know the effects of pruning to reduce glyphosate phytotoxicity severity in eucalypt concluded that early pruning facilitated the safe application of glyphosate. However, 10 $\%$ pruning in plants caused negative effects that compromised growth and could be seen up to 640 days after glyphosate spraying (Machado et 
al., 2014). The proper definition of the intensity of pruning that does not compromise eucalypt growth and facilitates weed control operations must be found out. To consider that glyphosate drift can lead to further damage is also essential.

Silva et al. (2014) evaluated the phytotoxicity of glyphosate $\left(720 \mathrm{~g}\right.$ a.e. $\left.\mathrm{ha}^{-1}\right)$ on $E$. urophylla seedlings, as well as the distribution and diameter of sprayed droplets with the spray nozzles AIUB 04 and TTI 11004. The spray nozzle TTI 11004 had higher volume median diameter, lower percentage of droplets smaller than $100 \mu \mathrm{m}$ and smaller coefficient uniformity of drops, extremely desirable features to prevent drift. Glyphosate spraying with AIUB 04 increased visual symptoms of phytotoxicity. However, glyphosate drift simulation reduced plant growth for both spray nozzles.

\section{HPPD inhibitor Isoxaflutole}

This herbicide has to be sprayed to soil, being absorbed predominantly by meristems and roots of the developing weed seedling during the germination/emergence process. Once in soil, water or plant isoxaflutole is quickly converted to diketonitrile (biologically active molecule), inhibiting the enzyme 4hydroxyphenylpyruvate dioxygenase (HPPD) and resulting in depletion of carotenoids and absence of chloroplast. The first leaves will appear bleached and stunted (Pallet et al., 1998).

Isoxaflutole is selective to eucalypt and can be sprayed on plants, since the dose and seedling size is respected. The optimal dose of isoxaflutole may vary according to soil type and infestation. Thus, to know soil texture and history of weed infestation in the area is essential to a good weed control (Marchiori Jr. et al., 2005).

The selectivity of isoxaflutole on $E$. globulus and E. saligna was tested by Agostinetto et al. (2010), being found that the average phytotoxicity was about $3 \%$, proving the selectivity of isoxaflutole in eucalypt seedlings.
Isoxaflutole residual effect under simulated drought periods in heavy clay soil and sandy clay loam soil and on Urochloa decumbens and Panicum maximum was studied by Marchiori Jr. et al. (2005). Isoxaflutole provided over $97 \%$ control in clay soil, regardless dose, weed specie or drought period. The herbicide stability has been lower in the sandy clay loam soil: species control was greater than $80 \%$ and persisted between 25 and 50 days to $U$. decumbens and between 50 and 120 days for $P$. maximum.

Carbonari et al. (2011) evaluated isoxaflutole weed control effectiveness by aerial application in clay granules (150 and $225 \mathrm{~g}$ i.a. $\mathrm{ha}^{-1}$ ) in comparison to a conventional spraying system. The lower dose of isoxaflutole provided low control levels to Urochloa decumbens, Ipomoea grandifolia, Merremia cissoides and Panicum maximum. The highest dose showed better results when sprayed conventionally. In the end of the experiment similar weed control was observed for both.

\section{ALS inhibitor \\ Imazapyr}

Imazapyr acts inhibiting the synthesis of acetolactate synthase (ALS), an essential enzyme for the synthesis of leucine, lysine and isoleucine, ceasing plants growth between 7 and 10 days after spraying (Oliveira Jr. et al., 2011). For eucalypt imazapyr should be used only for forest areas eradication (Rodrigues and Almeida, 2005).

Imazapyr root exudation by eucalypt and its effects on seedlings were verified in the literature. Imazapyr toxic effects were observed in the entire volume of soil reached by Eucalyptus grandis and E. urophylla root system (Souza et al., 2006). After cutting eucalypt plants sorghum was planted, and symptoms of sorghum phytotoxicity increased with increasing doses of imazapyr. The dose of $93 \mathrm{~g}$ a.i. ha ${ }^{-1}$ would not allow the regrowth of the four eucalypt clones (Souza et al., 2006). However, researches about imazapyr exudation 
and its effects on subsequent eucalypt seedlings are still scarce.

\section{Microtubule Formation Inhibitors}

These herbicides inhibit the polymerization of microtubules, causing physical reconfiguration and loss of function. The spindle is not formed and the alignment and separation of chromosomes during mitosis no longer occurs (Oliveira Jr. et al., 2011).

Seedlings roots and shoots growth are paralyzed, and the apical meristem may also die. Grasses grown from seeds will be efficiently controlled, but the same do not happen with broad-leaved weeds. These herbicides have little or no translocation, and weeds already established will hardly be controlled by microtubule inhibitors.

They are surface-sprayed in preemergence of weeds or alternatively incorporated into soil before planting (high vapor pressure, photolysis and microbial degradation) (Oliveira Jr. et al., 2011). They can also be strongly adsorbed by soil particles and soils rich in organic matter; strong adsorption to soil can hinder the absorption of the herbicide by radicle. The recommendation of those herbicides should take into account the content of organic matter in the soil (Rodrigues and Almeida, 2011).

In eucalypt, oryzalin, pendimenthalin and trifluralin may be used as pre-emergence herbicides.

\section{Glutamine synthetase inhibitor Glufosinate-ammonium}

Glufosinate-ammonium is a broad spectrum herbicide with foliar absorption and xylem and phloem translocation, inhibiting the enzyme glutamine synthetase (GS) in chloroplasts, blocking the synthesis of glutamate and glutamine. This enzyme is important in the route that converts inorganic nitrogen in organic compounds. Inhibition of GS leads to rapid ammonia accumulation, resulting in cells destruction, photosystem I and
II inhibition, and loss of chloroplasts structure (Oliveira Jr. et al., 2011).

The first symptom observed will be chlorotic leaves followed by wilted leaves. Plant death will happen in one or two weeks.

\section{Outlooks and Needs for Weed Chemical Control in Eucalypt}

The choice of herbicides to be used in forest areas should always consider history of area, identification of target weeds and knowledge of weeds biology; to forecast possible changes in weed community over the years; the competitive potential of Eucalyptus and its tolerance to accidental drifts and choosing the right spraying technique. Safe herbicides and safe methods are employed to protect man and environment and to reduce the impact of weed control and operational costs.

Glyphosate are still excessively used for weed control in eucalypt. Weeds that are not controlled by glyphosate anymore (tolerant and resistant species) are already common knowledge, and were reported in several crops. After years of exclusive glyphosate sprayings in eucalypt weed species can possibly be reported as tolerant or resistant too. However, it is known glyphosate is widely used because it's costeffective, and as in other crops, stop using glyphosate is not an easy or quick process.

So, maybe a new herbicide selective to Eucalyptus species to promote grasses control and to be sprayed in early post-emergence of weeds may help the Brazilian forest sector. This herbicide can be alternated with or complement the herbicides we have to be sprayed in preemergence of weeds (isoxaflutole, sulfentrazone and oxyfluorfen) controlling grasses efficiently and reducing glyphosate use in the first year after eucalypt seedlings planting.

Another option to reduce the glyphosate use and consequently prevent tolerant or resistant species is to offer new herbicides. There are herbicides for weed management used in other countries but still not allowed in Brazil. Some of these are being tested here or even had 
their "behavior" initially studied on our soils, species, clones and environmental conditions through drift simulation experiments. Some herbicides used in other countries or with research initiated in Brazil include: acetochlor (Villalba et al., 2010); 2,4-D, atrazine and diuron (Brasil et al., 1976); chlorimuron-ethyl (Brighenti et al., 2015); clomazone (Takahashi et al., 2009); fluroxypyr, fomesafen, haloxyfopmethyl, indaziflam, lactofen, metsulfuronmethyl, paraquat, sethoxydim+diclosulam (Agostinetto et al., 2010); saflufenacil, metolachlor, sulfometuron-methyl (Blazier et al., 2012), terbacil + sulfometuron-methyl (Churchill and Beadle, 2011; Osiecka and Minogue, 2015), triclopyr (Tuffi Santos et al., 2006) and fluroxypyr + triclopyr (Carvalho et al., 2014).

Some of these herbicides possibly have great potential in eucalypt, and more research in this area should be encouraged. These surveys should consider and evaluate the positioning of herbicides, soil type and stage of plants, adjuvants use and adjustments in spraying technology. Another important aspect is the differential selectivity between species and clones, which can be seen throughout this review. Once more, herbicide mode of action rotation is essential, considering herbicides allowed to be sprayed in eucalypt presented throughout this review.

Eucalypt areas can be found throughout Brazil and strategies of weed control should be adapted to different conditions. Reports of weed community and studies about spraying technology (techniques adapted to the climatic conditions of the North, for example) should be performed. There is also lack of information about floristic composition and weed control in that region. Thus, phytosociological surveys are a demand to remove this limitation from Brazilian forestry sector. Many reforestation companies are expanding their forest areas to the North and Northeast of Brazil, and certainly are in need of information to optimize weed management. Collaborations between these reforestation (which is aware of difficulties and has large areas to be studied) and universities or research groups (which should conduct research and use the available scientific knowledge to find solutions to the difficulties found) are crucial and should be established.

Studies with multivariate analysis techniques, using information as eucalypt species or clones; weeds species; weeds infestation rate; visual herbicide control; history of herbicides sprayed in the area and weather conditions are still scarce in eucalypt, but are common to sugarcane, for example (Kuva et al., 2008; Ferreira et al., 2011; among others). These data combination can allow knowing main weed species in the area; potential infestation; species/clones behavior in presence of weeds and informations about the real contribution of sprayed herbicides to weed control.

In order to make herbicides use more efficient, new technologies must be developed and tested. In some areas, polyacrylamide gel is applied on the seedlings awaiting planting, and at planting time, to help keep seedlings moisture. Offer herbicides through this gel performing a "chemical crown" would be very interesting. After planting, seedlings are irrigated, typically every 3,5 or 7 days, so other possibility would be to offer herbicides through irrigation water, or in combination with inert materials, in order to increase herbicide performance or control (Bezutte et al., 1995; Carbonari et al., 2010). However, more studies are necessary.

To adopt the chemical control as the exclusive method in weed management is uneconomic and may result in an imbalanced production system. Most areas are currently using minimum tillage. This system is very interesting for forest areas since many residues after harvest are left in the area, creating a large layer of forestry coverage, such as leaves, branches and bark. This layer ends up drowning out soil, and protecting soil from solar radiation, becoming a natural weed control for some time (depending on temperature, rainfall, decomposition rate, among others). Different 
weed species have different needs, and the amount and distribution of this coverage are essential at this time to ensure weed control for a while.

However, the time between harvest and planting new seedlings can be long, and at this time weeds may be bigger than eucalypt seedlings. Typically, the first glyphosate spray is performed at this time. Again, the coverage originated from burndown can be used as weed control (considering quantity and distribution), and timing between harvesting and soil preparation should be planned to avoid weed community establishing. At this moment, a preemergence herbicide selective to eucalypt is very interesting. After a good herbicide recommendation (soil free of clods + dose adjusted according to soil type + spray solution preparation + efficient spraying techniques), couple or more months of weed control will be ensured. However, monitoring the area is required, as well as control species that "escaped" to pre-emergence herbicides.

Attention to forestry certifications must be constant and consulting the herbicides that can be sprayed in the area to achieve or maintain a certification should be performed before planning any treatment. In general, "certification" confirms that a forest area is in accordance with predetermined principles and criteria, and evaluations of production systems are regularly made.

Studies about the optimization of forest practices in eucalypt areas are still scarce, but deserve attention and can be quite promising to optimize the time spent with it and reduce costs onindividual pesticide treatments. Brighenti et al. (2015) sprayed herbicides alone (glyphosate, isoxaflutole and oxyfluorfen) or combined with boron on Eucalyptus urograndis. The presence of boric acid in the spraying solution mixed with herbicides did not affect weed control, but still increase boron content in the soil and consequently in E. urograndis leaves.

Monitoring activities and use of indicators to evaluate the viability and quality of forestry activities are rarely also made. The available information usually focuses on the seedlings (nursery) and is scarce in the field routine. Soares et al. (2015) worked with 19 performance indicators in five different perspectives in forestry (financial, customer, internal processes, learning and growth and market). The indicators that "gained more weight" in the evaluations (and therefore were the critical factors for the success of a forestry enterprise) were the herbicide dose, the spraying equipment conditions and employees training.

The "adoption" of new technologies to study weeds should be seen as tools that provide essential information. Proteomics, transcriptomics and metabolomics techniques, for example, have been used to understand mechanisms of herbicide tolerance and weed resistance.

With the introduction of transgenic eucalypt which changes can occur? These changes can affect weed control? Faced with a transgenic crop weed species can be selected, making it hard to control/tolerant/resistant? Control eucalypt regrowth after harvesting is easily and efficiently done by imazapyr. Changes can occur for a transgenic eucalypt?

Challenges will always be part of weed control, and the forestry sector should be prepared to foresee it, and if necessary, solve it.

\section{References}

Adams, P.; Beadle, C.; Mendham, N.; Smethurst, P. The impact of timing and duration of grass control on growth of young Eucalyptus globulus Labill plantation. New Forests, v.26, p.147-165, 2003.

Agostinetto, D.; Tarouco, C.P.; Markus, C.; Oliveira, E.; Silva, J.M.B.V.; Tironi, S.P. Seletividade de genótipos de eucalipto a doses de herbicidas. Semina: Ciências Agrárias, v.31, n.3, p.585-598, 2010.

Bezutte, A.J.; Calegare, F.; Alves, P.L.C.A.; Pitelli, R.A. Eficiência do herbicida oxyfluorfen, quando veiculado ao papel, no 
controle de algumas espécies daninhas. Planta Daninha, v.13, n.1, p.39-45, 1995.

Blazier, M.A.; Johnson, J.; Taylor, E.L.; Osbon, B. Herbicide site preparation and release options for eucalyptus plantation establishment in the western gulf. In: Proceedings of the 16th Biennial Southern Silvicultural Research Conference, 2012, Ashville, U.S. Proceedings... p.19-23.

Bradshow, L.D.; Kimball, S.L.; Wells, B.H. Perpectives on glyphosate resistence. Weed Tecnology, v.11, p.189-198, 1997.

Brasil, U.M.; Fernandes, P.S.; Simoes, J.W.; Ferreira, J.E.F. Emprego de herbicidas na implantação de povoamentos de Eucalyptus saligna sm. IPEF, n.13, p.123-134, 1976.

Brasil. Ministério da Agricultura, Pecuária e Abastecimento. Agrofit. Disponível em: <http://agricultura.gov.br/agrofit>. Acesso em: 21 Out. 2015.

Brighenti, A.M.; Muller, M.D.; Oliveira Junior, A.; Castro, C. Weed control and boron nutrition on Eucalyptus in silvopastoral system. Tropical and Subtropical Agroecosystems, n.18, p.3946, 2015.

Carbonari, C.A.; Velini, E.D.; Gomes, G.L.G.C.; Takahashi, E.N.; Araldi, R. Seletividade e absorção radicular do sulfentrazone em clones de eucalipto. Planta Daninha, v.30, n.1, p.147-153, 2012.

Carbonari, C.A.; Velini, E.D.; Gomes, G.L.G.C.; Takahashi, E.N.; Bentivenha, S.R.P. Aplicação aérea de grânulos de argila como veículo de herbicidas para o controle de plantas daninhas em área de reforma de eucalipto. Revista Brasileira de Herbicidas, v.10, n.3, p.257-265, 2011.

Carvalho, G.P.; Silva, A.A.; Nunes, T.V.; Barbosa, F.A.; Silva, J.I.C.; Cerqueira, F.B. et al. Deriva simulada de triclopyr e fluroxypyr + triclopyr no desenvolvimento de mudas de clones de Eucalyptus. Revista Árvore, v.38, n.1, p.165-173, 2014.
Carvalho, L.B.; Alves, P.L.C.A.; Costa, F.R. Differential response of clones of eucalypt to glyphosate. Revista Árvore, v.39, n.1, p.177187, 2015.

Churchill, K.; Beadle, C. "Eucmix": An evaluation of the feasibility of using a selective residual herbicide to control weeds in directseeding revegetation trials. In: Cooperative Research Centre for Forestry Technical Report 192. Hobart, Australia, 2011. p.1-8.

Coppen, J.J. The Genus Eucalyptus. Taylor and Francis e-Library, 2005. 450p.

Cruz, M.B.; Alves, P.L.C.A.; Karam, D.; Ferraudo, A.S. Capim-colonião e seus efeitos sobre o crescimento inicial de clones de Eucalyptus urograndis. Ciência Florestal, v.20, n.3, p.391-401, 2010.

Ferreira, M.C.; Di Oliveira, J.R.G.; Dal Pietro, I.R.P.S. Distribuição da calda herbicida por pontas de pulverização agrícola utilizadas em áreas de reflorestamento com eucalipto. Engenharia Agrícola, v.29, n.2, p.267-276, 2009.

Ferreira, R.V.; Contato, E.D.; Kuva, M.A.; Ferraudo, A.S.; Alves, P.L.C.A.; Magario, F.B.; Sangado, T.P. Organização das comunidades infestantes de plantas daninhas na cultura da cana-de-açúcar em agrupamentos-padrão. Planta Daninha, v.29, n.2, p.363-371, 2011.

Florence, R.G. Ecology and silviculture of eucalypt forests. Australia: CSIRO, 2004. 413 p.

Florentine, S.; Fox, J. Competition between Eucalyptus vitrix seedlings and grass species. Ecological Research, v.18, p.25-39, 2003.

Garau, A.M.; Ghersa, C.M.; Lemcoff, J.H.; Barañao, J.J. Weeds in Eucalyptus globulus subsp. maidenii (F. Muell) establishment: effects of competition on sapling growth and survivorship. New Forests, v.37, p.251-264, 2009.

George, B.H.; Brennan, P.D. Herbicides are more cost- effective than alternative weed 
control methods for increasing early growth of Eucalyptus dunnii and Eucalyptus saligna. New Forests, v.24, p.147-163, 2002.

Graat, Y.; Rosa, J.O.; Nepomuceno, M.P.; Carvalho, L.B.; Alves, P.L.C.A. Grass weeds interfering with eucalypt: effects of the distance of coexistence on the initial plant growth. Planta Daninha, v.33, n.2, p.203-211, 2015.

Hakamada, R.E.; Arthur Junior, J.C.; Gonçalves, J.L.M.; Pulitto, A.P. Levantamento sobre o manejo de plantas daninhas. In: Reunião técnico-científica do PTSM, 40., 2010, Campo Grande. Anais... p.44-64.

IBA. Indústria Brasileira de Árvores. Disponível em <www.bracelpa.org.br/>. Acesso em: 2 out. 2015.

Kuva, M.A.; Ferraudo, A.S.; Pitelli, R.A.; Alves, P.L.C.A.; Salgado, T.P. Padrões de infestação de comunidades de plantas daninhas no agroecossistema de cana-crua. Planta Daninha, v.26, n.3, p.549-557, 2008.

Little, K.M.; Van Staden, J.; Clarke, G.P.Y. Eucalyptus grandis and E. camaldulensis variability and intra-genotypic competition as a function of different vegetation management treatments. New Forests, v.25, p.227-242, 2003.

Machado, M.S.; Ferreira, L.R.; Oliveira Neto, S.N.; Ferreira, G.L.; Fontes, D.R.; Machado, A.F.L. Métodos de controle de plantas daninhas e desrama precoce no crescimento do eucalipto em sistema silvipastoril. Planta Daninha, v.32, n.1, p.133-140, 2014.

Machado, M.S.; Ferreira, L.R.; Oliveira Neto, S.N.; Moraes, H.M.F.; Gonçalves, V.A.; Felipe, R.S. Eucalyptus growth in silvopastoral system under different crown diameters. Planta Daninha, v.31, n.4, p.851-857, 2013.

Marchiori JR., O.; Constantin, J.; Oliveira JR., R.S.; Inoue, M.H.; Pivetta, J.P.; Cavalieri, S.D. Efeito residual de isoxaflutole após diferentes períodos de seca. Planta Daninha, v.23, n.3, p.491-499, 2005.
Oliveira JR., R.S.; Constantin, J.; Inoue, M.H. Biologia e Manejo de Plantas Daninhas. Curitiba: Omnipax, 2011. 348 p.

Osiecka, A; Minogue, P.J. Sequential sulfometuron methyl applications in Eucalyptus benthamii plantations. Weed Technology, v.29, p.243-254, 2015.

Pallett K.E.; Little J.P.; Sheekey, M.; Veerasakaran $\mathrm{P}$. The mode of action of isoxafutole: 1. Physiological effects, metabolism and selectivity. Pesticide Biochemistry and Physiology, v.62, p.113124, 1998.

Pereira, F.C.M.; Alves, P.L.C.A.; Martins, J.V.F. Interference of grasses on the growth of eucalyptus clones. Journal of Agricultural Science, v.5, n.11, p.173-180, 2013.

Pereira, F.C.M.; Yamauti, M.S.; Alves, P.L.C.A. Interação entre manejo de plantas daninhas e adubação de cobertura no crescimento inicial de Eucalyptus grandis x $E$. urophylla. Revista Árvore, v.36, n.5, p.941949, 2012.

Pereira, M.R.R.; Rodrigues, A.C.P.; Campos, C.F.; Melhorança Filho, A.L.; Martins, D. Absorção de subdoses glyphosate aplicadas em diferentes locais de plantas de eucalipto. Revista Árvore, v. 35, n.3, p.589-594, 2011.

Rockwood, D.L.; Peter, G.F. Eucalyptus and Corymbia species for pulpwood, mulchwood, energywood, windbreaks, and/or phytoremediation. In: University of Florida Cooperative Extension Service Publication \#CIR1194, 2011. p.1-7.

Rodrigues, B.N.; Almeida, F.S. Guia de herbicidas. 5. ed. Londrina: Grafmarke, 2005. 591p.

Rodrigues, B.N.; Almeida, F.S. Guia de herbicidas. 6 . ed. Londrina: Produção Independente, 2011. 697p.

Salgado, T.P.; Alves, P.L.C.A.; Kuva, M.A.; Takahashi, E.N.; Dias, T.C.S.; Lemes, L.N. Sintomas de intoxicação inicial de eucaliptos 
proporcionados por subdoses de glyphosate aplicadas no caule ou nas folhas. Planta Daninha, v.29, n.4. p.913-922, 2011.

Silva, B.P.; Machado, A.A.; Fonseca, E.D.; Ferreira, M.C. Distribuição, diâmetro de gotas e fitoxicidade de herbicidas aplicados em mudas de eucalipto com pontas de indução de ar. Revista Brasileira de Herbicidas, v.13, n.3, p.225-234, 2014.

Silva, J.R.V.; Alves, P.L.C.A.; Toledo, R.E.B. Weed control strip influences the initial growth of Eucalyptus grandis. Acta Scientiarum Agronomy, v.34, n.1, p.29-35, 2012.

Soares, P.R.C.; Timofeiczyk Junior, R.; Silva, J.C.G.L.; Milan, M. Sistema de medição de performance para o controle de plantas invasoras em plantações florestais. Revista Floresta, v.45, n.1, p.175-184, 2015.

Souza, G.V.R.; Ferreira, L.R.; Sediyama, C.S.; Silva, C.M.M.; Tuffi Santos, L.D.; Viana, R.G. Exsudato radicular de imazapyr aplicado sobre mudas de diferentes clones de eucalipto. Planta Daninha, v.24, n.1, p.141-147, 2006.

Souza, L.S.; Velini, E.D.; Maiomonirodella, R.C.S. Allelopathic effect of weeds and concentrations of Brachiaria decumbens on the initial development of eucalyptus (Eucalyptus grandis). Planta Daninha, v.21, n.3, p.343354, 2003.

Souza, M.C.; Alves, P.L.C.A.; Salgado, T.P. Interferência da comunidade infestante sobre plantas de Eucalyptus grandis de segundo corte. Scientia Forestalis, v.38, n.85, p.63-71, 2010.

Takahashi, E.N.; Alves, P.L.C.A.; Salgado, T.P.; Farias, M.A.; Silva, A. C.; Biaggioni, B.T. Consequências da deriva de clomazone e sulfentrazone em clones de $E$. grandis x $E$. urophylla. Revista Árvore, v.33, n.4, p.675683, 2009.

Tarouco, C.P.; Agostinetto, D.; Panozzo, L.E.; Santos, L.S.; Vignolo, G.K.; Ramos, L.O.O. Períodos de interferência de plantas daninhas na fase inicial de crescimento do eucalipto.
Pesquisa Agropecuária Brasileira, v.44, n.9, p.1131-1137, 2009.

Tiburcio, R.A.S.; Ferreira, F.A.; Ferreira, L.R.; Machado, M.S.; Machado, A.F.L. Controle de plantas daninhas e seletividade do flumioxazin para eucalipto. Cerne, v.18, n.4, p.523-531, 2012a.

Tiburcio, R.A.S.; Ferreira, F.A.; Paes, F.A.S.V.; Melo, C.A.D.; Medeiros, W.N. Crescimento de mudas de clones de eucalipto submetidos à deriva simulada de diferentes herbicidas. Revista Árvore, v.36, n.1, p.65-73, 2012 b.

Tuffi Santos, L.D.; Cardoso Filho, O.; Santos Júnior, A.; Sant'anna-Santos, B.F.; Felix, R.C.; Leite, F.P. Floristic and structural variation of weeds in eucalyptus plantations as influenced by relief and time of year. Planta Daninha, v.31, n.3, p.491-499, 2013.

Tuffi Santos, L.D.; Ferreira, F.A.; Ferreira, L.R.; Duarte, W.M.; Tiburcio, R.A.S.; Santos, M.V. Intoxicação de espécies de eucalipto submetidas à deriva do glyphosate. Planta Daninha, v.24, n.2, p.359-364, 2006.

Tuffi Santos, L.D.; Ferreira, F.A.; Meira, R.M.S.A.; Barros, N.F.; Ferreira, L.R.; Machado, A.F.L. Crescimento e morfoanatomia foliar de eucalipto sob efeito de deriva do glyphosate. Planta Daninha, v.23, n.1, p.133142, 2005.

Tuffi Santos, L.D.; Meira, R.M.S.A.; Ferreira, F.A.; Sant'anna-Santos, B.F.; Ferreira, L.R. Morphological responses of different eucalypt clones submitted to glyphosate drift. Environmental and Experimental Botany, v.59, p.11-20, 2007.

Velini, E.D.; Trindade, M.L.B.; Alves, E.; Catâneo, A.C.; Marino, C.L.; Maia, I.G. et al. Eucalyptus ESTs corresponding to the protoporphyrinogen IX oxidase enzyme related to the synthesis of heme, chlorophyll, and to the action of herbicides. Genetics and Molecular Biology, v.28, n.3, p.555-561, 2005. 
Villalba, J.; Montouto, C.; Cazaban, J.; Caraballo, P.; Bemtancu, O. Efecto del laboreo sobre la eficacia de herbicidas y el crecimiento de Eucalyptus spp. Agrociencia Uruguay, v.14, n.2, 2010. 